\title{
Phytochemical Evaluation and In Vitro Antioxidant Study of Adiantum latifolium
}

\author{
Dr. Beena Thomas, Diya Thomas, S. Amatha, K.H Krishna, Meeramol.C.Chellappan* \\ Department of pharmaceutical sciences, RIMSR, Centre for Professional and Advanced Studies, Kottayam-, Kerala, India. \\ *Corresponding author's E-mail: meerachennamattam@gmail.com
}

Received: 05-04-2021; Revised: 19-05-2021; Accepted: 26-05-2021; Published on: 15-06-2021.

\section{ABSTRACT}

Adiantum latifolium an important medicinal plant belonging to the family adiantaceae. The plant is scientifically proved to use as antiinflammatory, analgesic, anti infectious, and diuretic. In this study, the antioxidant property of extract of Adiantum latifolium leaves was evaluated using the antioxidant assay techniques like reducing power assay and phosphomolybdate assay. The extract of Adiantum latifolium was prepared after drying using cold extraction method and ethanol extraction. The extract prepared was phytochemically evaluated and the antioxidant study was carried out using phosphomolybdate assay and reducing power assay using ethanolic extract. Thus, reducing power assay concludes the antioxidant activity increase with increase in concentration and phosphomolybdate assay confirms the antioxidant activity. Thus, this study concludes the antioxidant activity of the leaves of Adiantum latifolium and further studies could be done to establish the same.

Keywords: Adiantum latifolium leaves extract, Cold extraction, Ethanol extraction, Reducing power assay, Phosphomolybdate assay.

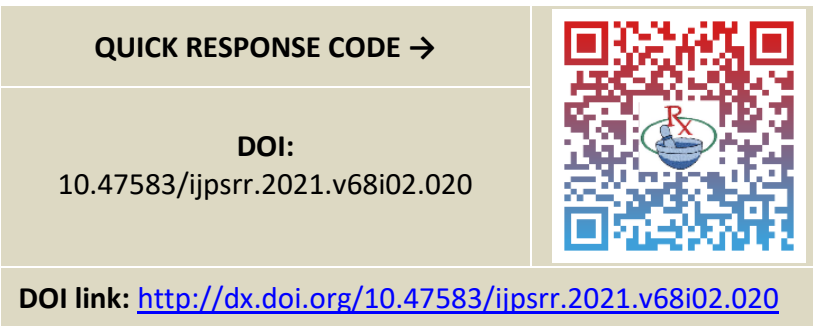

\section{INTRODUCTION}

$\mathrm{n}$ today's modern world, the risk of diseases due to oxidative stress is compounded by unhealthy lifestyle, exposure of chemicals, pollution, cigarette smoking, drugs, illness, and stress etc. Exogenous consumption of

anti-oxidants from plant, animal, and mineral sources have proved beneficial to human health and effective to reduce the incidence of free radical induced diseases. The antioxidants are also associated with reduction of free radical generation and improves antioxidant status in patients, thus it may be beneficial to recover normal function and treatment of such diseases. In recent years there has been increased interest in the therapeutic use of antioxidants in the treatment of disease associated with oxidative stress. Several studies reported that low antioxidant intake or low blood levels of antioxidants increase the risk of different diseases, in fact low dietary intake of fruits and vegetables double the risk of cancer. Therefore, wholesome antioxidant diet and natural antioxidant supplements as part of a healthy lifestyle are now being recognised to protect health from oxidative stress.

Adiantum latifolium is popularly called "maiden hair fern" because of the shiny black rachis of the leaves. It is one of the most widely distributed genera of the family
Pteridaceae. The plant Adiantum latifolium, is widely employed world wide as antiinflammatory, analgesic, antiinfectious, and diuretic. Studies were undertaken to establish the antinociceptive and anti-inflammatory properties of the methanolic extract of Adiantum latifolium leaves and to investigate the mechanisms responsible for its effects ${ }^{2,3}$.

\section{MATERIALS AND METHODS}

\section{Collection, authentication and drying of plant material}

Plant material of Adiantum latifolium was collected from surroundings of DPS, CPAS Puthuppally campus. The plant was authenticated by Dr. Rojimon P Thomas, Head of the Department of Botany, CMS College, Kottayam. The whole plant collected was washed for removing the dust and dirt. The leaves of Adiantum latifolium were shade dried separately for 15 days. The shade dried material was powdered using Mechanical grinder.

\section{Extraction}

\section{Cold aqueous extraction}

$10 \mathrm{~g}$ of air dried powder of leaves of Adiantum latifolium was weighed and soaked separately in $50 \mathrm{ml}$ cold water in a conical flask, stoppered with rubber cork and left uninterrupted for $24 \mathrm{hrs}$ and then filtered off using muslin cloth into a conical flask and concentrated using water bath evaporation, where by the solvent was evaporated at its boiling temperature $100^{\circ} \mathrm{C}$. The concentrated extract was again filtered using muslin cloth and was subjected to centrifugation at $5000 \mathrm{rpm}$ for 5 minutes and the supernatant was obtained and stored at $4^{\circ} \mathrm{C}$ in a refrigerator for further use.

Ethanol extract $10 \mathrm{~g}$ of air dried powder of leaves of Adiantum latifolium was weighed and was placed in $100 \mathrm{ml}$ 
of organic solvent (ethanol) in a conical flask and then kept in a rotary shaker at $190-220 \mathrm{rpm}$ for $24 \mathrm{hrs}$, it was filtered with the help of muslin cloth and centrifuged at $5000 \mathrm{rpm}$ for 15 minutes. The supernatant was collected and the solvent was evaporated to make the final volume to onefourth of the original volume, giving a concentration of 100 $\mathrm{mg} / \mathrm{ml}$ and stored at room temperature in air tight container ${ }^{4}$.

\section{The phytochemical analysis}

The leaf extract of Adiantum latifolium was analysed for the presence of flavonoids, alkaloids, glycosides, steroids, phenols, saponins and terpenoids ${ }^{5}$.

\section{Evaluation of in vitro antioxidant activity of ethanolic extracts of adiantum latifolium}

\section{Reducing power assay}

The total antioxidant activity can be measured by the reducing antioxidant power assay. The antioxidant compounds present in the sample form a colored complex with potassium ferricyanide, trichloroacetic acid and ferric chloride, which is measured at $700 \mathrm{~nm}$ using UVSpectrophotometer.

\section{Preparation of standard and test solution}

$100 \mathrm{mg}$ extract was dissolved in ethanol and made up to $50 \mathrm{ml}$ in a standard flask, the concentration of the test sample being $2 \mathrm{mg} / \mathrm{ml}$. Other concentrations of the samples were prepared by diluting $2.5 \mathrm{ml}, 5 \mathrm{ml}, 7.5 \mathrm{ml}$ and $10 \mathrm{ml}$ of the above solution and made up to $10 \mathrm{ml}$ with ethanol, each having a concentration of $0.5 \mathrm{mg} / \mathrm{ml}$, $1 \mathrm{mg} / \mathrm{ml}, 1.5 \mathrm{mg} / \mathrm{ml}$ and $2 \mathrm{mg} / \mathrm{ml}$ respectively. Reference compound ascorbic acid also was prepared in the same concentrations under similar dilutions with water from standard ascorbic acid solution $(2 \mathrm{mg} / \mathrm{ml})$.

Working Procedure: To $1 \mathrm{ml}$ of the different concentrations of the extract $(0.5 \mathrm{mg} / \mathrm{ml}, 1 \mathrm{mg} / \mathrm{ml}, 1.5 \mathrm{mg} / \mathrm{ml}, 2 \mathrm{mg} / \mathrm{ml})$ mixed in distilled water then mix $2.5 \mathrm{ml}$ of $0.2 \mathrm{M}$ phosphate buffer ( $\mathrm{pH} 6.6)$ and $2.5 \mathrm{ml}$ of $1 \%$ potassium ferricyanide $\left[\mathrm{K}_{3}\right.$ Fe $\left.(\mathrm{CN})_{6}\right]$. The same concentrations of standard ascorbic acid, prepared in the similar way used as standard solution. All the solutions were incubated at $50^{\circ} \mathrm{C}$ for 20 minute. Then, the reaction was terminated by adding $2.5 \mathrm{ml}$ of $10 \%$ trichloroacetic acid and the mixture was centrifuged at 650 $\mathrm{rpm}$ for $10 \mathrm{~min}$. The upper layer of solution $(2.5 \mathrm{ml}$ ) was mixed with the distilled water $(2.5 \mathrm{ml})$ and $0.5 \mathrm{ml}$ of $0.1 \%$ $\mathrm{FeCl}_{3}$ was added. Blank solution was prepared in the same way without adding any extract. Then the absorbance was measured at $700 \mathrm{~nm}$ in a spectrophotometer against a blank sample ${ }^{4,6}$.

\section{Phosphomolybdate assay}

The antioxidant activity of samples was evaluated by the green phosphomolybdenum complex formation.

\section{Preparation of the standard and the test solution}

$10 \mathrm{mg}$ of plant extract was dissolved in $1 \mathrm{ml}$ of DMSO. Then $100 \mu \mathrm{l}, 50 \mu \mathrm{l}, 10 \mu \mathrm{l}$ was pipette out and made up to $10 \mathrm{ml}$ using DMSO to give the desirable concentrations.

Standard ascorbic acid was prepared using same dilutions to get the same concentrations.

\section{Working procedure}

$100 \mu \mathrm{l}$ from each concentrations prepared sample was taken and $1 \mathrm{ml}$ of reagent solution was added to it and incubated in a boiling water bath at $95^{\circ} \mathrm{C}$ for $90 \mathrm{~min}$. After $90 \mathrm{~min}$, the absorbance of the solution was read at $695 \mathrm{~nm}$. Ascorbic acid $(10 \mathrm{mg} / \mathrm{ml})$ was used as the standard. The Phosphomolybdenum reduction potential (PRP) of the studied extracts were reported in percentage ${ }^{7-10}$.

\section{RESULTS}

\section{Phytochemical screening}

The results of the phytochemical screening of extracts of leaves of Adiantum latifolium revealed the presence of phytoconstituents such as flavonoids, saponins, carbohydrates, steroids, phenols.

Table 1: Results of phytochemical analysis

\begin{tabular}{|c|c|c|}
\hline $\begin{array}{c}\text { Chemical } \\
\text { constituents }\end{array}$ & $\begin{array}{c}\text { Ethanolic } \\
\text { extract }\end{array}$ & $\begin{array}{c}\text { Aqueous } \\
\text { extract }\end{array}$ \\
\hline Alkaloids & $-v e$ & -ve \\
\hline Saponins & $+v e$ & $+v e$ \\
\hline Triterpenes & $-v e$ & $-v e$ \\
\hline Carbohydrate & $+v e$ & $+v e$ \\
\hline Steroids & $+v e$ & $+v e$ \\
\hline Proteins & $-v e$ & $-v e$ \\
\hline Flavonoids & $+v e$ & $+v e$ \\
\hline Phenols & $+v e$ & $+v e$ \\
\hline Cardiac glycosides & $-v e$ & $-v e$ \\
\hline
\end{tabular}

\section{Antioxidant assay}

1. Reducing power assay

Table 2: Results of reducing power assay

\begin{tabular}{|c|c|c|}
\hline $\begin{array}{c}\text { Concentration } \\
(\mathbf{m g} / \mathrm{ml})\end{array}$ & $\begin{array}{c}\text { Absorbance } \\
\text { of Test }\end{array}$ & $\begin{array}{c}\text { Absorbance of } \\
\text { Standard } \\
\text { (Ascorbic acid) }\end{array}$ \\
\hline 0.5 & 0.092 & 0.178 \\
\hline 1 & 0.268 & 0.572 \\
\hline 1.5 & 0.302 & 0.735 \\
\hline 2 & 0.342 & 0.940 \\
\hline
\end{tabular}




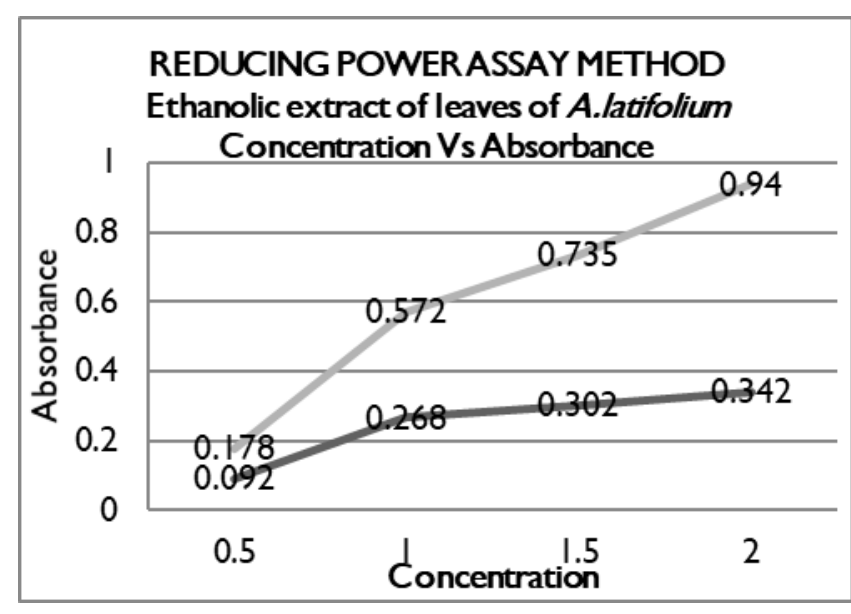

Standard test

Graph 1: Reducing power of the extract from Adiantum latifolium

\section{Phosphomolybdate assay}

Table 3: Results of Phosphomolybdate Assay.

\begin{tabular}{|c|c|c|c|}
\hline $\begin{array}{c}\text { Concentration } \\
(\boldsymbol{\mu g} / \mathrm{ml})\end{array}$ & $\begin{array}{c}\text { Absorbance } \\
\text { of Standard }\end{array}$ & $\begin{array}{c}\text { Absorbance } \\
\text { of Test }\end{array}$ & \% Inhibition \\
\hline 10 & 0.674 & 0.574 & 14.83 \\
\hline 50 & 0.848 & 0.702 & 17.21 \\
\hline 100 & 0.997 & 0.722 & 27.58 \\
\hline
\end{tabular}

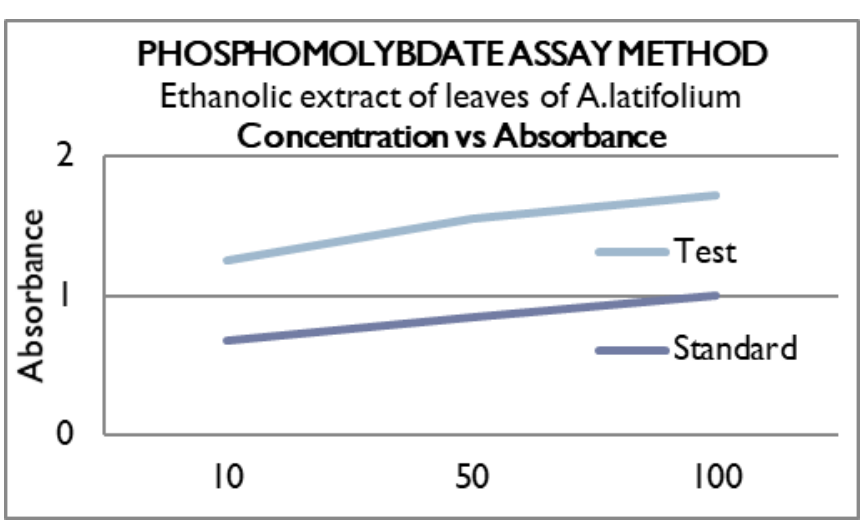

Graph 2: Phosphomolybdate assay of ethanolic extract of Adiantum latifolium

Percentage inhibition $=$ Absorbance of Standard - Absorbance of Test $\times 100$ Absorbance of Standard

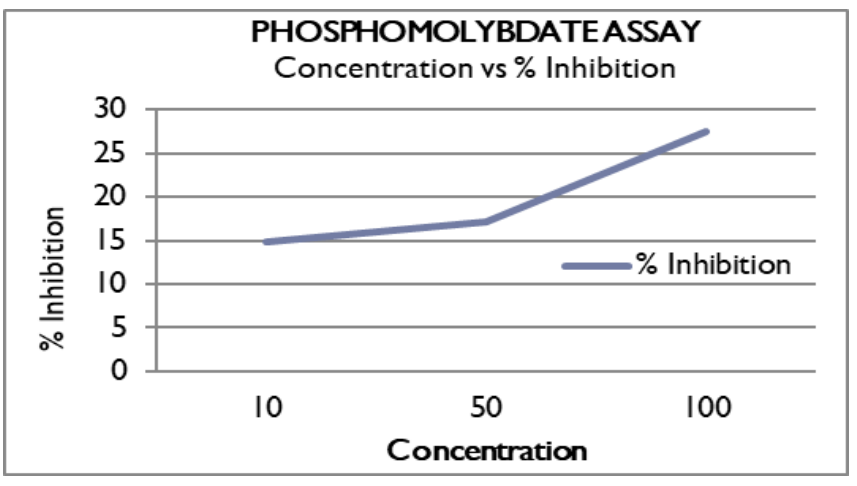

Graph 3: Percentage inhibition graph of phosphomolybdate assay

\section{CONCLUSIONS}

Natural antioxidants that are present in herbs are responsible for inhibiting or preventing the deleterious consequences of oxidative stress. It contains free radical scavengers like flavonoids and phenolic compounds. In this study, we have evaluated the free radical scavenging activity of ethanolic extract of Adiantum latifolium. Adiantum latifolium is one of the most interesting plants in the family Adiantaceae known for its diversified habits, gregarious nature. Adiantum latifolium is a highly potential medicinal plant in Ayurveda. The leaves are useful in traditional medicine as anxiolytic, analgesic and antiinflammatory. In the present study, aqueous and ethanolic extracts of leaves of Adiantum latifolium were used. The preliminary phytochemical screening of extracts showed the presence of flavonoids, saponins, phenols, carbohydrates, steroids. The ethanolic extract was used for antioxidant studies. The study was carried out using two tests - reducing power assay and phosphomolybdate assay. The reducing power assay determines the total antioxidant activity by the comparative analysis with that of standard and the study concluded that the antioxidant activity increases with increase in concentration and they are comparable with that of standard at each concentration. Phosphomolybdate assay confirms the antioxidant activity by formation of phosphomolybdenum complex. The antioxidant activity was calculated using percentage inhibition, where the percentage inhibition increased the antioxidant activity also increased. The maximum inhibition was shown at the concentration of $100 \mu / \mathrm{ml}$.

Thus, this study concludes the antioxidant activity of the leaves of Adiantum latifolium and further studies could be done to establish the same.

\section{REFERENCES}

1.Raja AM, Sahithi G, Vasanthi R, Banji D, Rao K and Selvakumar D. Study of phytochemical and antioxidant activity of Cucumis melo var. agrestis fruit. Journal of Pharmacognosy and Phytochemistry 2015; 4:; 303-306.

2. Kregel K, Zhang H. An integrated view of oxidative stress in aging: basic mechanisms, functional effects, and pathological considerations. American Journal of Physiology-Regulatory, Integrative and Comparative Physiology. 2007;292(1): R18-R36.

3. Masaki $\mathrm{H}$. Role of antioxidants in the skin: Anti-aging effects. Journal of Dermatological Science. 2010; 58 (2): 85-90.

4. Winter W, Amoroso V. Plant resource of South-East Asia cryptogams: ferns and fern allies.Prosea foundation, Borgor, Indonesia, 2003:15(2):268.

5.Yumkhan S, Elangbam M, Nongmaithem R, Naorem $P$, Singh P. Maiden hair ferns (Adiantum L., PteridaceaeVittarioideae) of North Eas India: diversity, phytochemistry and utilization. Generic Resources and Crop Evolution. 2018;65(4):1269-1280. 
6. Black O, Newton R, Huang J, Lima T. Systematical interleukin I administration suppresses arachidonic acidinduced ear oedema in the mouse. The British Journal of Dermatology.1989:121:701-707.

7.Rajurkar N, Gaikward K. Evaluation of phytochemicals, antioxidant activity and elemental content of Adiantum capillus veneris leaves. Journal of chemical and pharmaceutical research, 2012,4(1):365-374.
8. Mitsuda H, Yasumoto K, Iwami K. Antioxidative action of indole compounds during the autooxidation of linoleic acid. Eiyo To Shokurya, 1966:19(1):210-214

9. Shrivastava A, Pandey B, Chauhan D. Phytochemical analysis of Adiantum and pteris ferns and its role as antioxidant. Indian J Sci, 2014:4(1):31-38.

10. Priyanka Y. Madhuca longifolia (Sapotaceae): a review of its traditional uses, phytochemistry and pharmacology. International Journal of Biomedical Research, 2012:3(7):291-305.

Source of Support: The author(s) received no financial support for the research, authorship, and/or publication of this article.

Conflict of Interest: The author(s) declared no potential conflicts of interest with respect to the research, authorship, and/or publication of this article.

For any question relates to this article, please reach us at: editor@globalresearchonline.net

New manuscripts for publication can be submitted at: submit@globalresearchonline.net and submit_ijpsrr@rediffmail.com 